\title{
Economic Growth, Policies and Influencing Factors: The Case of Albania
}

\author{
Dr. Eleni Vangjeli
}

*Corresponding author, University "Fan S. Noli" Korce, Faculty of Economy, Department of Finance, Albania

elenivangjeli@yahoo.com

Dr. Anila Mancka

University "Fan S. Noli" Korce, Faculty of Economy. Department of Finance, Albania

arapi_anila@yahoo.com

\begin{abstract}
Monetary and fiscal policies are two policies that the government could use to keep a high level of growth, with a low inflancion. Fiscal policy has its initial impact on the stock market, while monetary policy in market assets. But, given that the goods and active markets are closely interrelated, both policies, monetary as well as fiscal have impact on the economy, increasing the level of product through the reduction of interest rates. In our paper we will show how functioning monetary and fiscal policies. But also in our paper we will analyze the different factors which have affected the economic growth of the country. The focus of our study is the graphical and empirical analysis of economic growth, policies and influencing factors. For the empirical analysis we have used data on the economic growth in Albania for $1996-2014$.
\end{abstract}

Keywords: Monetary and fiscal policies, economic growth, export growth, FDI, economic indicators, Political stability

\section{INTRODUCTION}

\section{Economic Growth in Albania}

From 1996 until 1999 year the Albanian economy has increased to high levels. After 2000 year, the economy growth has suffered declining. Then has continuing of sustainable growth with averaging $6 \%$ per annum, this for the period until the end of 2008.

The global crisis exerted significant pressure on the economy. As a result of the global crisis, the growth rates were lowered considerably. Real growth in 2009 year, was halved from its historical trend, but continued to be positive (3. $3 \%$ of GDP), as a result of limited financial exposure to international markets and expansionary fiscal policy initiated before the crisis. Because of strong economic links of trade with Italy and Greece, the crisis in these countries was reflected in the decrease in remittances and exports in the Albanian economy, which led to a significant slowdown of economic growth and particularly of budget revenues. The economy has continued with a moderate growth rate of $3.8 \%$ in 2010 year and 3.1 $\%$ in 2011. In 2012 year and throughout 2013, economic growth is weakening further. The growth rate decreased to 1. 3\% in 2012 and continued to fall sharply during 2013 year. During the nine months of 2013 the economic growth estimated INSTAT resulted in $0.4 \%$ compared with the same period of a year ago. Domestic demand remains very weak and the prospects for an immediate acceleration of private consumption and investment remain poor. Foreign demand has been 
the main driver of growth in the past two years, however, it remains conditioned by unfavorable developments in the economies of the euro zone and non-diversified base of exporters, both in terms of products, as well as markets.

For 2014, the World Bank estimates that Albania has had an economic growth at 2. 1\%.

Although INSTAT are not doing nearly as data that has been the economy in the final quarter of last year, the World Bank estimated that there has been increasing, although it is modest.

For 2015 the forecast of the bank is the level that has the Albanian government program, and estimated the economy to grow by $3 \%$, as well as the global economy.

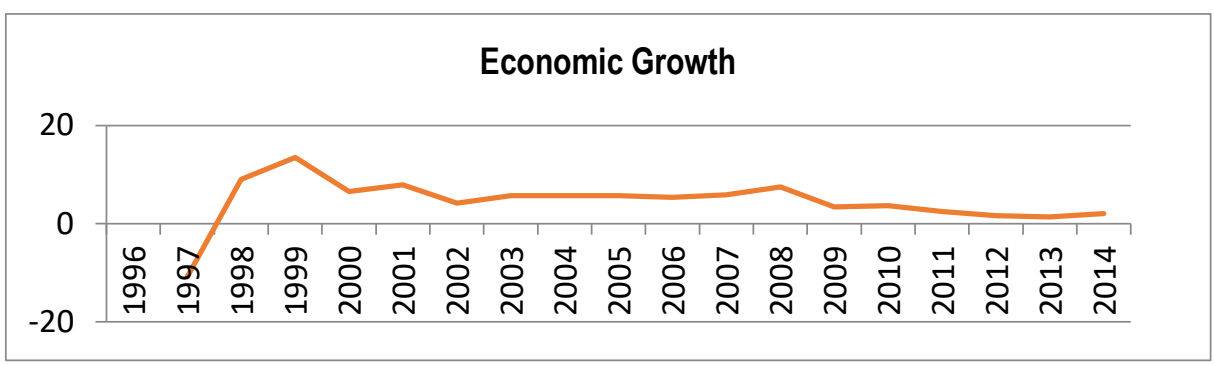

Source: INSTAT Database

\section{Economic Policies in Albania}

During 2002 and onwards, cyclic economic poverty and low inflation pressures demanded to pursue a stimulating monetary policy. Facilitating monetary policy of the Central Bank caused the interest deposit and credit rates to decrease in minimal levels. This affected the demand for credit by increasing the investments.

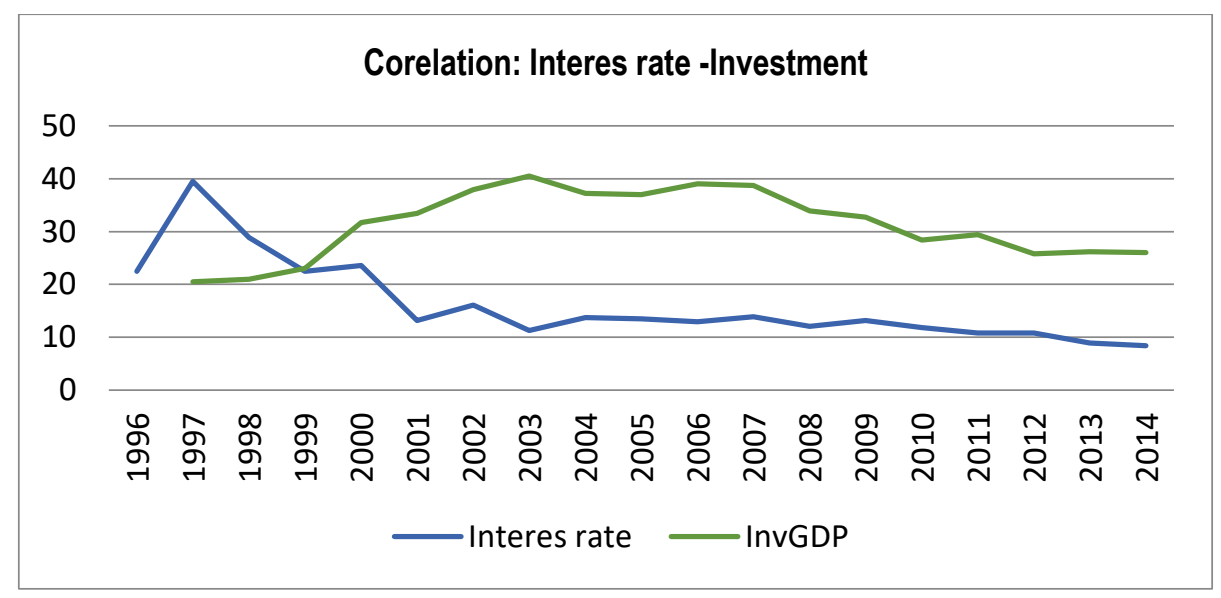

As shown in the graphic, it results that reduction of interest rates after 2000 encouraged the investments. The correlation coefficient between these two indicators is $\left(-.503^{*}\right)$ statistically important [See Appendix ], showing a negative moderated relationship which means that if interest rates decrease, investments increase. Increase of investments and improvement of balance of trade with other countries have been a support to the economic growth. 


\section{Corelation: Economic Growth- Investment}

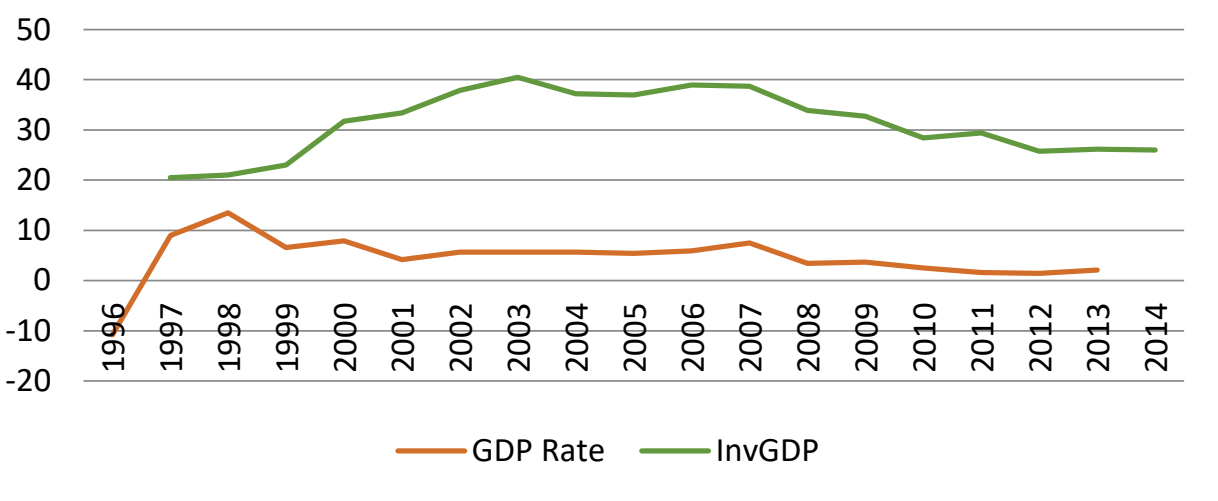

A strong relationship between the economic growth and the investments is seen after 2007, where investment and the economic growth moved with the same trend. The correlation coefficient for this period is $(0.830)$ statistically important which shows a strong relation between these indicators. For the period between 1996-2007 the relationship between investments and the economic growth is very weak, the correlation coefficient for this period is low $(0.173)$ and statistically not important. Based on an evaluation from the Bank of Albania, the investments' increase in 2008-2013 was affected even by the reduction of business non-safety indicator. The relations between business insecurity and investments in economy and customers' insecurity with the private consumption are reciprocal. In times when insecurity is reduced, the economic indicators record an increase and vice versa.

During the last ten years, the foreign investment flows played an important role to the productivity, production, employment and exports in the country's economy.

From the monetary policies' point of view, the inward FDI flows are important since they affect the exchange rates and the balance of payments

Besides FDI, another influence in increasing the demand was the increase of consumption mainly for 2008 even when the consumer's insecurity indicator was low. For the period between 2008-2013, the increase of consumer's insecurity indicator reduced the private consumption by reducing mainly the consumption of long-term goods which have an elastic demand. Ensuring a sustainable economic growth and targeting inflation would require keeping a stimulating monetary policy for middle term period. The monetary stimulus provides the time necessary for making structural reforms which provide a longterm economic growth and tone down the costs of these reforms. Structural reforms aim to improve sustainably the business climate, increase the production and competitiveness of the Albanian economy in increasing the economic-financial sustainability in the country.

Effects of the fiscal policy in the economic growth are determined by increasing the government expenditures and tax changes. But, increasing the government expenditure and reducing taxes increase the budget deficit. Fiscal stimulus is determined by changes in the primary deficit report to the GDP. Positive changes of these reports show positive stimulus whereas negative differences signal fiscal consolidation. 


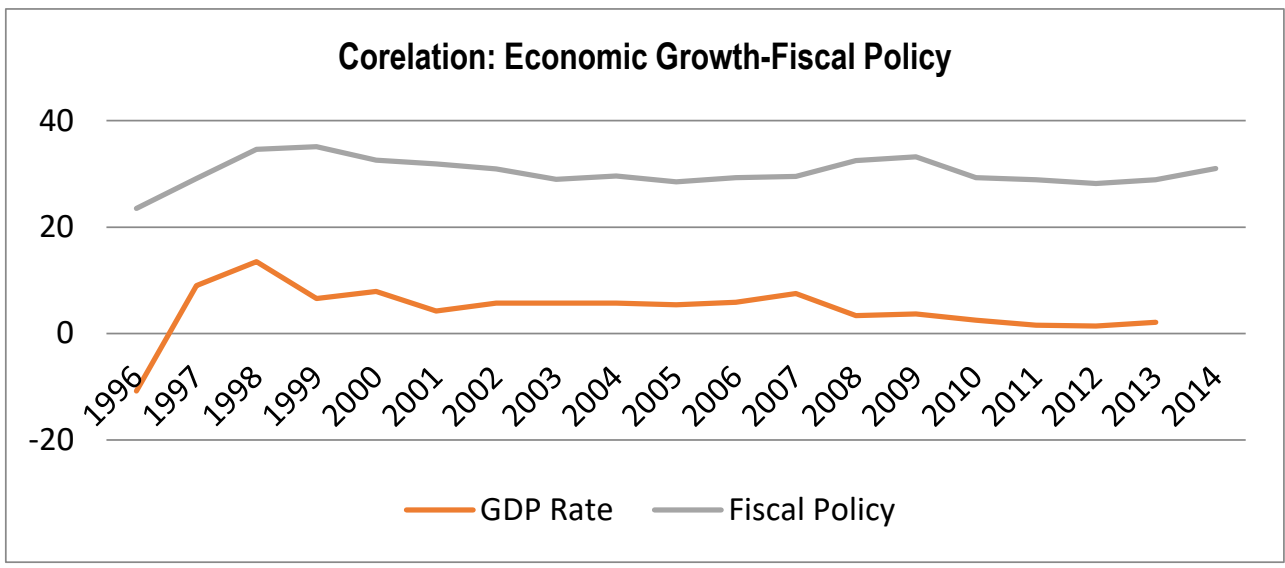

The chart shows that the increase of government expenditures and the increasing pace of domestic product had the same trend. Such an increase of fiscal consolidation is accompanied with a growth of GDP. The correlation coefficient between these two indicators is $\left(0.707^{*}\right)$ [See the Appendix], showing a strong positive relationship.

\section{Empirical Analyze and Influencing Factors}

Based on the above analysis we conclude that some of the factors which have affected the economic growth in Albania are the domestic investments, FDI, and improvement of balance of trade. Of course, the economic growth was affected by other factors, but the above are the ones we will analyze. In order to determine the general influence of these factors on economic growth, we will perform the empirical analysis by building a multiple regression model. In building such a model, we considered the previous empirical studies in the area by adopting it to the country's conditions. Before we build the empirical model and determine the affecting factors, we analyzed the correlation for each factor related to the other ones. Reciprocal correlation between factors was analyzed: domestic investments - FDI - balance of trade. Correlating analysis resulted in:

Domestic investments - FDI. [Correlation coefficient $=0$. 994]

Domestic investments - balance of trade/GDP. [Correlation coefficient $=-0.398$ ]

$\mathrm{FDI}$ - balance of trade/GDP. [Correlation coefficient $=-0.338$ ]

By analyzing the above correlations, we see that there is a strong relation between domestic investments and FDI. Since there is multicollinearity, one of the variables - domestic investments - is not included in the model. This is because we should present a more real picture of other independent variables' influence (FDI, NX/GDP) to the dependent variable such as GDP, and analyze the importance of influence of each independent variable to the dependent one.

Given the conditions, affecting factors will be FDI and balance of trade. Meanwhile, another affecting factor will be considered the political stability which is a very important factor for the economic growth in our country.

\section{LITERATURE BACKGRAUND}

Contemporary literature offers more materials from different scholars who have analyzed the influence of affecting factors on economic growth. We have analyzed some of them here.

Empirical studies has shown that growth of trade in goods with other countries or reduction of protectionism was associated with a higher economic growth. Eduarts (1998) explains that besides factors as capital accumulation, labor force growth, 
including differences in the level of technology, countries with low scale of the protectionism tend faster than countries with large trade restrictions. In his empirical study Harrison (1991) studied the relationship between the opening of the economy and the economic growth between different countries concluded that the level of openness of the economy has positive impact on GDP growth. Trade was therefore linked with economic development describing trade liberalization as an engine of growth.

This view is confirmed by Obadan (1994b), when he stressed that trade plays the role of engine of economic growth, especially through increased specialization and exports. Trade leads to the separation of labor. This in turn increase the growth of the country's GDP.

Mwaba (1999) concluded that increased of trade opening tends to rise the level of economic growth. In their study Dollar and Kraay (2001), based on data for 100 countries, analyzed the relationship between the change in the level of trade and economic growth. Their results showed that there was a strong positive relationships between the level of trade and economic growth.

In later studies, Obadan and Elisabeth (2008) analyzed the influence of trade on the Economic Development in Nigeria. Their resultsshowed that trade openness has a positive impact on Nigeria's economic growth.

The role of foreign direct investment (FDI) in the country's economic development is widely debated, according with various opinions for and against. Many countries have welcomed FDI as an essential contribution to the development processes and facilitate entry into the world economy, it is appreciated in a wider context of strategic reforms for economic restructuring and development. Empirical studies acknowledge the role of FDI in economic growth and development of host countries, especially in emerging economies. Alfaro (2003) studied the effects of FDI on growth in the primary, manufacturing and services sectors. Her results showed that benefits of FDI vary greatly across sectors.

Borensztein et. al. (1998) in their investigation evaluated the effects of FDI in economic growth relying on data for the period 1970 to 1979 and from 1980 to 1989 for 69 development countries. Their results showed that FDI have positive effect on economic growth, although the magnitude of this effect depends on the quality of the human capital of the host country. So in countries with very low levels of human capital the direct effect of FDI is negative. Carkovic. M and Levine. R (2002) studied the effects of FDI on economic growth of the host country. In their study they reached the conclusion that the effects of growth of FDI depends on the level of education of the host country, the level of economic development, the level of financial development and the of trade opening. Alfaro et. al (2003) in their empirical analysis examined the various links between FDI, financial markets and economic growth using cross-country data for the period 1975-1995. Their results showed that FDI as indicators play a ambitious role contributing to economic growth. Blomstrom. M and Kokko. A (2003) in their study reached the conclusion that FDI can play an important role in raising the technological level of a country, creating new employment and contributing to economic growth. Shaari et. al (2012) in their study analyzed the impact of FDI in real GDP in Malaysia. They analyzed the data of 1980-2010 period using Ordinary Least Square method. Results showed that FDI helps to reduce unemployment rate and increase economic growth (GDP) in Malaysia. If we refer to the economic stability, the empirical studies have shown that economic growth influenced by this factor. Alesina. A et. al (1992) studied this relationships by analyzing the data of 113 countries for the period of 1950-1982. In their study they reached the conclusion that the political instability and economic growth are closely linked. The main result of their study was that countries that for a long period of time the government has collapsed economic growth has been lower than in other countries.

\section{THEORETICAL ANALYZE}

The influencing factors on economic growth that we have chosen are as following:

The degree of trade openness (NX/GDP)

Foreing Direct Investment (FDI)

Political Stability (PLS) 
We have chosen Global Domestic Product (GDP)as the dependent variable, while the index of the opening of the economy and FDI are independent variables. Political stability is used as a dummy variable. Increased foreign trade affects on economic growth. This factor is associated with the variable of economic openness indicator which is calculated as rate of trade balance divided by GDP, (X - M) / GDP. This variable is used as an approximation of the level of a country's trade with the rest of the world. Opening trade has a positiv impact to economic growth. The expected signs of this variable is positive. FDI has positive effect on economic growth so expected signs of this variable is positive. Also, political stability has a positive impact on economic growth and expected signs of this variable is positive. The variable description are displayed in Table No. 1

Table no. 1 Variables Description

\begin{tabular}{|l|l|l|l|}
\hline Variables & $\begin{array}{l}\text { Priori } \\
\text { hypothesis }\end{array}$ & Definition & Units \\
\hline $\begin{array}{l}\text { The degree of trade openness } \\
\text { NX/GDP }\end{array}$ & positive sign & Indicator of current account & $\%$ \\
\hline Foreign Direct Investment & positive sign & Indicator of financial account & Million/lek \\
\hline Political Stability & positive sign & $\begin{array}{l}\text { Indicator of economic development of the } \\
\text { country }\end{array}$ & $\begin{array}{l}\text { Dummy } \\
\text { variable }\end{array}$ \\
\hline
\end{tabular}

\section{SPECIFICATION OF MODEL}

We have established the following hypothesis:

$H_{0}$ : Choosen variableshave no effect on economic growth

$\mathrm{H}_{1}$ :Choosen variableshave positive effects on economic growth

Based on the analysis of the variables the functional appearance of the model will be:

$\mathrm{GDP}=\mathrm{f}(\mathrm{NX}, \mathrm{FDI}, \mathrm{PLS})$

Linear equation that expresses the relationship between the explanatory variables has the form:

$G D P=\beta_{0}+\beta_{1} N X+\beta_{2} F D I+\beta_{3} P L S+\mu_{t}$

Expected sign variables is:

$\beta_{1,>0,} \beta_{2}>0, \beta_{3,}>0$

We will test the model base on the following hypothesis:

$H_{0}: \beta_{1}=0, \beta_{2}=0, \beta_{3}=0$

$H_{1}:$ At least one $\beta \neq 0$

For testing the hypothesis was used the time series of data for the period 199-2014 which received by the Bank of Albania, INSTAT and the Ministry of Finance. 
Base on the data of the time series was done the regression analysis using the program SPPS-21. The test results are shown in the tables at the APPENDIX of this paper.

\section{EMPIRICAL RESULT}

Based on the results of the test the model is significant. Acording Anova table of the Fisher test the significance coefficient is $\left(.000^{b}\right)<0.05$,sothe independent variables in the model explain better the dependent variable. Since Adjusted R Square $=0.950$, the model's explicability is high, so, the dependent variable variation is explained with the changes of dependent variables.

All the independing variables have effect on depending variabel. Also, according $T$ test all the independent variables are significant because the coefficients for each factor are less than $<0$. 05. (See Table no. 2). The results are displayed in Table No. 2

Table no. 2 Summary of multiple regression results

\begin{tabular}{|l|l|l|l|}
\hline Variables & $\begin{array}{l}\text { Unstandardized Coefficients } \\
\beta\end{array}$ & $\begin{array}{l}\text { Standardized Coefficients } \\
\beta\end{array}$ & Significance \\
\hline (Constant) & 816502.214 & & .002 \\
\hline NX/GDP & 20175.657 & .141 & .055 \\
\hline FDI & 697.502 & .812 & .000 \\
\hline Political Stability & 225081.045 & .316 & .001 \\
\hline
\end{tabular}

1. Based on this results the equation will be:

2. $\mathrm{GDP}=\beta_{0}+20175.6 \mathrm{NX}+697.5 \mathrm{FDI}+225081 \mathrm{PLS}+\mu_{\mathrm{t}}$

3. All the independing variables have the expected sign. So nul hypothesis are rejected and $\mathrm{H}_{1}$ hypothesis are accepted. The coefficient before the variable in the regression equation affects the dependent variable (GDP) when respective independent variables change per unit. From the regression equation we see that all variables have an important influence on GDP.

\section{SUMMARY AND CONCLUSIONS}

5. As the world economic recovery is followed by a high uncertainty degree, the Albanian economy records positive increasing rates.

6. Besides the important contribution of foreign demand on export increase, application of a facilitating monetary policy and the follow-up of fiscal incentive, have encouraged recently the increase of domestic demand affecting positively the domestic product.

7. From the empirical study we have concluded that there is an important relationship between the affecting factors we have considered and the economic growth.

8. According the result of empirical study trade openness - economic growth relation is positive. The higher the export, the higher the economic growth.

9. Therefore, the increase of foreign demand by stimulating exports affects positively the economic growth. So, exports are the most important factor since they affect largely the economic growth. FDI are considered useful in economic growth. In the context of transitional economies toward a market economy and the trends of economic integration and globalization, FDI are given the priority for the better of economy in general. Determining the FDI flows effect on domestic demand is important in the stabilization process of the economy through monetary policy means. But, it is important that monetary decision makers understand the influence they have on acceleration of inflation pressures or unemployment rate effects. 10. According the empirical study, the relation between GDP and FDI is positive. This conclusion supports the estimation that FDI are an important source in developing the country's economy. Based on the results of the study, the political stability affects the economic growth and this effect is statistically important. The relationship between the economic growth 
and the political stability is positive. Therefore, we conclude that if the country is characterized by a political stability, this will affect largely the economic growth.

\section{REFERENCES}

[1] Alfaro, Laura, Areendam Chanda, Sebnem Kalemli-Ozcan, And Selin Sayek. (2003) "FDI And Economic Growth: The Role of Local Financial Markets. " Harvard Business School. Working Paper 01-083 Journal of International Economics

[2] Alfaro, L. (2003). "FDI and Growth: Does the sector matter"?, Harvard Business School

[3] Alfaro, Chanda, Kalemli-Ozcan, dhe Sayek. ( 2006). "How does FDI Promote Economic Growth? Exploring the Effects of Financial Marketson Linkages", Journal of Development Economic,vol. 61.

[4] Aliber, R. Z. (1970). A theory of direct foreign investment. Cambridge: MIT Press.

[5] Blomstrom. Mand Kokko. A (2003)“The Economics of Foreign Direct Investment Incentives” Working Paper 168 January 2003

[6] Blomstrom dhe Kokko. (1998). "Multinational Corporations and Spillovers", Journal of Economic Survey vol. 12.

[7] Borenstein, De Gregorio, E. \& Lee, J. W. (1998). "How does foreign direct investment affect economic growth"?, Journal of International Economics, vol. 45, fq. 115-135.

[8] Bank of Albania (2010) "Financial Stability Report" October 2010

[9] Bank of Albania (2010) "Monetary Policy Report" October 2010

[10] De Gregorio, J (1994) "Haw does the Foreign Direct Investment Affect The Economic Growth "NBER Working Paper Nr 5057

[11] Dollar, D and A. Kraay (2001), "Growth is Good for the Poor", World Bank Research Working Paper. Dollar, D (1992), "Outward - Oriented Developing Countries Really do Grow More Rapidly: Evidence from 95 LDCs, 1976 - 85", Economic Development and Cultural Change, April, 523 - 544.

[12] Edwards, S. (1998), "Openness, Productivity and Growth: What do we really Know?" Economic Journal, 108(1): $383-98$.

[13] Obadan and Elisabeth (2008) "An empirical analysis of the impact of trade on economic growth in Nigeria" Jos Journal of Economics, vol. 4, no.

[14] Shaari. M, Hong. Th, Shukeri. S "Foreign Direct Investment and Economic Growth: Evidence from Malaysia"International Business Research Vol. 5 No. 10(2012)

\section{APENDIKS}

\section{Table of Regression}

\section{Variables Entered/Removed}

\begin{tabular}{|l|l|l|l|}
\hline Model & Variables Entered & Variables Removed & Method \\
\hline 1 & $\begin{array}{l}\text { Stabilpolitic, } \\
\text { OpenNxGDP, FDI }\end{array}$ & & Enter \\
\hline
\end{tabular}

a. Dependent Variable: GDP

b. All requested variables entered.

\section{Model Summary}




\begin{tabular}{|l|l|l|l|l|}
\hline Model & R & R Square & Adjusted R Square & Std. Error of the Estimate \\
\hline 1 & $980^{\mathrm{a}}$ & .960 & .950 & 74687.43902 \\
\hline
\end{tabular}

a. Predictors: (Constant), Stabilpolitik, OpenNxGDP, FDI

ANOVA $^{a}$

\begin{tabular}{|ll|l|l|l|l|l|}
\hline Model & & Sum of Squares & df & Mean Square & F & Sig. \\
\hline 1 & Regression & 1720144325005.867 & 3 & 573381441668.622 & 102.789 & $.000^{\mathrm{b}}$ \\
& $\begin{array}{l}\text { Residual } \\
\text { Total }\end{array}$ & 72516776115.898 & 13 & 5578213547.377 & & \\
\hline
\end{tabular}

a. Dependent Variable: GDP

b. Predictors: (Constant), Stabilpolitic, OpenNx/GDP, FDI

Coefficients $^{\mathrm{a}}$

\begin{tabular}{|ll|l|l|l|l|l|}
\hline Model & \multicolumn{2}{|l|}{ Unstandardized Coefficients } & Standardized & $\mathrm{t}$ & Sig. \\
\cline { 3 - 6 } & & B & Std. Error & Beta & & \\
\hline \multirow{4}{*}{1} & (Constant) & 816502.214 & 208215.550 & & 3.921 & 002 \\
& OpenNx/GDP & 20175.657 & 9555.750 & .141 & 2.111 & 055 \\
& FDI & 697.502 & 61.554 & .812 & 11.332 & 000 \\
& Stabilpolitic & 225081.045 & 56017.109 & .316 & 4.018 & 001 \\
\hline
\end{tabular}

Dependent Variable: GDP

Table of Correlations

\begin{tabular}{|ll|l|l|}
\hline & & GDP Rate & InvGDP \\
\hline GDP Rate & Pearson Correlation & 1 & -191 \\
& Sig. (2-tailed) & & 462 \\
& N & 18 & 17 \\
& Pearson Correlation & -191 & 1 \\
& SigvG. (2-tailed) & 462 & \\
& $\mathrm{~N}$ & 17 & 18 \\
\hline
\end{tabular}

\section{Correlations}

\begin{tabular}{|ll|l|l|}
\hline & & GDP Rate & FiscalPolicy \\
\hline \multirow{6}{*}{ GDP Rate } & Pearson Correlation & 1 & $707^{* *}$ \\
& Sig. (2-tailed) & & 001 \\
& $N$ & 18 & 18 \\
FiscalPolicy & Pearson Correlation & $707^{* *}$ & 1 \\
& Sig. (2-tailed) & 001 & \\
& $\mathrm{~N}$ & 18 & 19 \\
\hline
\end{tabular}

*. Correlation is significant at the 0.01 level (2-tailed).

\section{Correlations}

\begin{tabular}{|ll|l|l|}
\hline & & InvGDP & GDP \\
\hline InvGDP & Pearson Correlation & 1 & 102 \\
& Sig. (2-tailed) & & 697 \\
& N & 18 & 17 \\
GDP & Pearson Correlation & 102 & 1 \\
& Sig. (2-tailed) & 697 & \\
& N & 17 & 18 \\
\hline
\end{tabular}

\section{Correlations}

\begin{tabular}{l|l|l|l|} 
InteresRate & InvGDP
\end{tabular}




\begin{tabular}{|ll|l|l|}
\hline \multirow{3}{*}{ InteresRate } & Pearson Correlation & 1 & $-.503^{*}$ \\
& Sig. (2-tailed) & & 033 \\
& $\mathrm{~N}$ & 19 & 18 \\
& Pearson Correlation & $-.503^{*}$ & 1 \\
InvGDP & Sig. (2-tailed) & .033 & \\
& $\mathrm{~N}$ & 18 & 18 \\
\hline
\end{tabular}

*. Correlation is significant at the 0.05 level (2-tailed). 